\title{
INTEGRIN BETA 4 mRNA EXPRESSION LEVELS IN BRONCHIAL ASTHMA PATIENTS
}

\author{
AbeerA. ALrefail,Rabab A. Elwahsh2and Nesreen G. Elhelbawy1 \\ 1Medical Biochemistry and 2Chest Departments \\ Faculty of Medicine, Menoufia University, Egypt \\ Received 19/2/2017- Accepted 19/3/2017
}

\begin{abstract}
Integrin beta 4 (ITG $\beta 4$ ) is one of the integrin families that is engaged in the maintenance of the integrity of airway epithelial cells. The aim of this work was to evaluate the relationship between ITG $\beta 4$ mRNA expression level and asthma susceptibility; and to analyze the relevance of atopic asthma with the alteration of ITG $\beta 4 \mathrm{mRNA}$ expression level.Seventy five asthmatic patients and thirty age and gender matched healthy controls were enrolled in this study. Serum total IgE was measured by ELISA and mRNA expression of ITG $\beta 4$ was assessed by reverse transcriptase PCR (RT-PCR) using real time PCR.. ITG $\beta 4$ mRNA expression was significantly down regulated with increased serum total IgE in patients with asthma compared to controls. Moreover, ITG $\beta 4$ expression was significantly reduced with increased total IgE in atopic asthmatics compared to non-atopic asthmatics.From this study, it could be concluded thatdown-regulation of ITG $\beta 4$ expression is associated with asthma susceptibility mainly in atopic cases irrespective of the degree of severity.
\end{abstract}

Key words: Integrin $\beta 4$, expression, asthma, atopy and RT- PCR.

\section{INTRODUCTION}

Bronchial asthma is an airway disorder with an allergic nature (Xiang et al., 2014). It is characterized by chronic inflammation with typical structural damage and airway epithelial cells dysfunction (Liu et al., 2010b), including shedding and metaplasia of epithelial layer, basement membrane thickening with increased susceptibility to outer stimuli (Holgate, 2007).

* Correspondence Author (e mail: (nesrin.eโhelbawy@yahoo.com) 
Membrane glycoprotein molecules, named as adhesion moleculesare expressed on the surface of many cell types (Charalambopoulos and Karachalios, 2000). They are responsible for the contact between two adjacent cells or between the cell and the extracellular matrix.They are involved in the physiological and pathological processes of asthma (Johansson and Mosher, 2013).

The integrin family of adhesion molecules, heterodimeric receptors that consist of paired $\alpha$ and $\beta$ subunitsthatfunction in adhesion and transduction(Acosta et al., 2016), are involved in migration, survival, proliferation, growth and differentiation of cells (Barczyk et al., 2010). One of these integrin families is integrin beta 4 (ITG $\beta 4$ ) that is engaged in the maintenance of the integrity of airway epithelial cells(Liu et al., 2010b). ITG $\beta 4$ is a laminin receptor that mediates the stable adhesion of epithelial cells to the basement membrane through hemidesmosomes architecture (Liu et al., 2010a). Damage of airway epithelial cell was common in asthmatic airway epithelial cells (Watt, 2002 and Sheppard, 2003).

Atopic asthma is characterized by Th2-mediated inflammation and typically impaired airway epithelial cells. In the airways of asthmatic patients, exposure to allergens induces an increase in Th2 cell infiltration and Th2 cytokine expression (Holgate and Davies, 2009 and Liu et al., 2012).

A previous study found that there was downregulation of integrin $\beta 4$ in the airway epithelium of asthmatic patients. As the airway epithelium is considered as the first barrier to allergen stimulation, downregulation of ITG $\beta 4$ enhanced the invasion of inhaled allergens and regulated the local $\mathrm{T}$ cell immune inflammation through antigen presentation process(Liu et al., 2010b).

The aim of the present study is to evaluate the relationship between ITG $\beta 4$ mRNA expression level and asthma susceptibility, and to analyze the relevance of atopic asthma with the alteration of ITG $\beta 4$ mRNA expression level.

\section{MATERIALS AND METHODS}

This study was carried out in Medical Biochemistry and Chest Departments, Faculty of Medicine, Menoufia University. 105 subjects were enrolled in the study; they were 75 asthmatic patients (36 males and 39 females) with mean age of $32 \pm 7.9$ and 30 age and 
gender matched healthy controls (14 males and 16 females)with mean age of $33.9 \pm 9.9$ The study was approved by ethical committee of Faculty of Medicine, Menoufia University. A written informed consent was obtained from all subjects. A clinical diagnosis of bronchial asthma wasbasedonthe characteristic pattern of respiratory symptoms such as wheezing, shortness of breath (dyspnea), chest tightness or cough, evidence of expiratory airflow limitation (FEV1/FVC less than 0.7).Bronchodilator (BD) reversibility test was carried out and was considered positive if there was an increase in FEV 1 of $>12 \%$ and $>200 \mathrm{~mL}$ from baseline, $10-15$ minutes after 200 mg salbutamol inhalation(GINA.2016).

Patients were classified into atopic and non atopic groups based on the family history of atopy, presence of history of identified allergen sensitivity and by measuring the level of immunoglobulin $\mathrm{E}$ ( $\mathrm{IgE}$ ) in serum. (Global Initiative for Asthma, 2016 and National Heart Lung and Blood Institute,2007). Serum $\operatorname{IgE}$ level $\geq 100 \mathrm{IU} / \mathrm{ml}$ is considered atopic and level $<100$ IU/mlisconsidered nonatopic(Abnova, USA). Severity of bronchial asthma in patients was assessed based on the GINA guidelines 2016 (Global Initiative for Asthma, 2016)and ERS/ATS guidelines (Chung KF et al., 2014) into mild, moderate and severe groups:

-Mild asthma is asthma that is well controlled with Step 1 or Step 2 treatment (i.e. with as-needed reliever medication alone, or with lowintensity controller treatment such as low dose ICS, leukotriene receptor antagonists or chromones).

-Moderate asthma is asthma that is well controlled with Step 3 treatment (e.g. low dose ICS/LABA).

-Severe asthma is asthma that requires Step 4 or 5 treatments (e.g. high-dose ICS/LABA, to prevent it from becoming 'uncontrolled', or asthma that remains 'uncontrolled' despite this treatment).

All patients who had any other cardiopulmonary disorders, acute exacerbation of asthma or evidence of other allergic diseases were excluded from the study.

\section{Methods:}

All subjects were subjected to: full history taking, general and local clinical examinations, chest $\mathrm{X}$ ray and pulmonary function tests (before and after bronchodilators, for asthmatic patients) including forced expiratory volume in one second / forced vital capacity ratio (FEV1/FVC) and postbronchodilator forced expiratory volume in one 
second(BDFEV1). Serum level of IgE was determined by ELISA technique (Abnova, USA). Measurement of Integrin $\beta 4 \mathrm{mRNA}$ expression was performed using reverse transcriptase PCR (RT-PCR) using real time PCR.

Samples collection:

Seven milliliters $(\mathrm{ml})$ of venous blood were withdrawn from each subject anddivided as follows: $3 \mathrm{~mL}$ in a vacutainerplain test tube andwas left to clot, and then centrifuged at 3000rpm for 10 minutes, serum was then separated and stored at $-80^{\circ} \mathrm{C}$ until used for measurement of serum IgElevel by ELISA. $4 \mathrm{~mL}$ of venous blood were delivered in a vacutainerEDTA-containingtube for detection of integrin $\beta 4 \mathrm{mRNAexpression.}$

Reverse transcriptase PCR (RT-PCR):

RNA was isolated from peripheral blood leukocytes using QIAamp RNA BloodMiniKit (Qiagen, USA, 2013), then assuring RNA concenrtation and purity by Nanodrop. First step-PCR: Complementary DNA was synthesized using QuantiTect Reverse Transcription Kit (Qiagen,AppliedBiosystems, USA, 2012),second step- PCR (real time PCRstep): it was performed using QuantiTect SYBR Green PCR Kit with ready made quantiTect Primer Assay, Qiagen.For measurement of integrin $\beta 4 \mathrm{mRNAlevels,} \mathrm{the} \mathrm{following}$ primers were used: forward and reverse primers of human integrin $\beta 4$, 5-AGACGAGATGTTCAGGGACC-3 and 5GGTCTCCTCTGTGATTTGGAA-3, respectively; forward and reverse primers for human glyceraldehyde-3-phosphate dehydrogenase (GAPDH) 5-CCACTCCTCCACCTTTGAC-3 and 5ACCCTGTTGCTGTAGCCA-3, respectively. PCR was conducted under the following conditions: 40 cycles; denaturation at $94 \mathrm{C}$ for $5 \mathrm{sec}$ annealing at $60 \mathrm{C}$ for $30 \mathrm{sec}$ and extension at $72 \mathrm{C}$ for $30 \mathrm{sec}$.

\section{Statistical analysis:}

The data collected was tabulated and analyzed by SPSS (statistical package for the socialscience) software version 16. Chi-square test is used to study the association between two qualitative variables. Student's t test was used to assess the statistical significance of parametric data. Mann-Whitney and Kruskal Wallis Test were used for nonparametric data.Spearman'scorrelation was used for skewed distributed quantitative variables. Values less than 0.05 were considered significant. 


\section{RESULTS}

The study enrolled 75 asthmatic patients and 30 age $(\mathrm{P}=0.3)$ and gender $(\mathrm{P}=0.9)$ matched apparently healthy individuals. Also, BMI $(\mathrm{P}=0.08)$ revealed non significant difference between the studied groups (table1).

There was a significant decrease in the level of Integrin $\beta 4$ mRNA expression in asthmatic patients $(2.88 \pm 2.44 \mathrm{Iu} / \mathrm{ml})$ compared to controls $(41.5 \pm 5.5 \mathrm{Iu} / \mathrm{ml})(\mathrm{P}<0.0001)$. While a significant increase in the serum level of $\mathrm{Ig} \mathrm{E}$ was found in these patients $(287.1 \pm 184.7 \mathrm{Iu} / \mathrm{ml})$ compared to controls $(34.8 \pm 2.7 \mathrm{Iu} / \mathrm{ml})(\mathrm{P}<0.0001)$ (table 1).

Regarding the asthmatic patients $56 \%$ were atopic and (44\%) of them were non- atopic patients, who revealed non- significant difference regarding airway obstruction parametersFEV1/FVC $(\mathrm{P}=0.98) \quad \&$ BDFEV1\% ( $\mathrm{P}=0.94)$ (table 2).

The serum IgElevels were significantly increased in atopic patients $(442.7 \pm 36.3 \mathrm{Iu} / \mathrm{ml})$ compared to non-atopic ones $(76.2 \pm 15.5 \mathrm{Iu} / \mathrm{ml})$ $(\mathrm{P}<0.0001)$. While there was a significant decrease of integrin $\beta 4$ mRNA expressionlevels in atopic patients $(1.6 \pm 1.96 \mathrm{Iu} / \mathrm{ml})$ compared to non-atopic $(4.6 \pm 1.92 \mathrm{Iu} / \mathrm{ml})(\mathrm{P}<0.0001)$ (table 2$)$.

Concerning the severity of asthma $33.3 \%$ of patients had mild degree of asthma, $40 \%$ had moderate degree and $26.7 \%$ suffered from severe asthma, who revealed non significant difference in the levels of Integrin $\beta 4$ mRNA expression $(\mathrm{P}=0.53)$ and serum $\operatorname{IgE}(\mathrm{P}=0.75)$ (table 3).

In asthmatic patients Integrin $\beta 4$ mRNA expression levels showed a significant negative correlation with serum levels of $\operatorname{Ig} E(r=-0.39$, $\mathrm{P}<0.001)$ and a significant positive correlation with $\mathrm{BMI}(\mathrm{r}=0.24$, $\mathrm{P}=0.043$ ) while there was no significant correlation between levels of both integrin $\beta 4 \mathrm{mRNA}$ expression and serum $\operatorname{IgE}$ and the other parameters (table 4\&5). 
Table 1: Demographic, clinical and laboratory characteristics of studied groups

\begin{tabular}{|c|c|c|c|}
\hline \multirow[b]{2}{*}{ Characteristics } & \multicolumn{2}{|c|}{ Studied groups } & \multirow[b]{2}{*}{ P-value } \\
\hline & $\begin{array}{c}\text { Patients } \\
(\mathbf{n}=75)\end{array}$ & $\begin{array}{c}\text { Controls } \\
(\mathbf{n}=30)\end{array}$ & \\
\hline $\begin{array}{l}\text { Age (years): } \\
\text { Mean } \pm \text { SD } \\
\text { Range }\end{array}$ & $\begin{array}{c}32 \pm 7.9 \\
18-42 \\
\end{array}$ & $\begin{array}{c}33.9 \pm 9.9 \\
20-50 \\
\end{array}$ & 0.3 \\
\hline $\begin{array}{l}\text { Gender }(\mathbf{n}, \%) \text { : } \\
\text {-Male } \\
\text {-Female }\end{array}$ & $\begin{array}{l}36(48) \\
39(52)\end{array}$ & $\begin{array}{l}14(46.7) \\
16(53.3) \\
\end{array}$ & 0.90 \\
\hline $\begin{array}{l}\text { BMI }\left(\mathrm{kg} / \mathrm{m}^{2}\right): \\
\text { Mean } \pm \text { SD } \\
\text { Range }\end{array}$ & $\begin{array}{c}25.8 \pm 1.15 \\
23.44-28.3\end{array}$ & $\begin{array}{c}25.4 \pm 0.96 \\
23.4-27.6\end{array}$ & 0.08 \\
\hline $\begin{array}{l}\text { FEV1/FVC: } \\
\text { Mean } \pm \text { SD } \\
\text { Range }\end{array}$ & $\begin{array}{c}62.8 \pm 6.9 \\
48-75\end{array}$ & - & - \\
\hline $\begin{array}{l}\text { BDFEV1 (\%): } \\
\text { Mean } \pm \text { SD } \\
\text { Range }\end{array}$ & $\begin{array}{c}70.4 \pm 12.9 \\
45-87\end{array}$ & - & - \\
\hline $\begin{array}{l}\text { Atopy }(\mathbf{n}, \%) \text { : } \\
\text {-Atopic } \\
\text {-Nonatopic }\end{array}$ & $\begin{array}{l}42(56 \%) \\
33(44 \%)\end{array}$ & - & - \\
\hline $\begin{array}{l}\text { Severity }(n, \%): \\
\text {-Mild } \\
\text {-Moderate } \\
\text {-Severe } \\
\end{array}$ & $\begin{array}{c}25(33.3) \\
30(40) \\
20(26.7) \\
\end{array}$ & - & - \\
\hline $\begin{array}{l}\text { Integrin } \beta 4 \quad \text { mRNA } \\
\text { expression (Iu/ml): } \\
\text { Mean } \pm \text { SD } \\
\text { Median(Range) }\end{array}$ & $\begin{array}{c}2.88 \pm 2.44 \\
2.29(0.02-5.83) \\
\end{array}$ & $\begin{array}{c}41.5 \pm 5.5 \\
43.3(35.0-48.7)\end{array}$ & $<0.0001 *$ \\
\hline $\begin{array}{ll}\text { IgE serum level } \\
(\text { Iu/ml): } \\
\text { Mean } \pm \text { SD } \\
\text { Median(Range) }\end{array}$ & $\begin{array}{c}287.1 \pm 184.7 \\
402(47-499)\end{array}$ & $\begin{array}{c}34.8 \pm 2.72 \\
35(31-39)\end{array}$ & $<0.0001 *$ \\
\hline
\end{tabular}

BMI: body mass index, FEV1: forced expiratory volume in one second, FEVC: forced vital capacity, BDFEV1: bronchodilator forced expiratory volume in one second, $\mathrm{t}$ : $\mathrm{t}$ test, ${ }^{\#}$ Chi square test- *MannWhitney test 
Table (2): Demographic, clinical and laboratory characteristics of atopic and non-atopic patients

\begin{tabular}{|c|c|c|c|}
\hline \multirow[b]{2}{*}{ Characteristics } & \multicolumn{2}{|c|}{ Patient group $(n=75)$} & \multirow[b]{2}{*}{ P-value } \\
\hline & $\begin{array}{c}\text { Atopic cases } \\
(n=42)\end{array}$ & $\begin{array}{l}\text { Non-atopic cases } \\
\quad(n=33)\end{array}$ & \\
\hline $\begin{array}{l}\text { Age (years) } \\
\text { Mean } \pm \text { SD } \\
\text { Range }\end{array}$ & $\begin{array}{c}31.5 \pm 7.7 \\
18-40\end{array}$ & $\begin{array}{c}32.7 \pm 8.2 \\
19-42\end{array}$ & 0.52 \\
\hline $\begin{array}{l}\text { Gender }(n, \%) \text { : } \\
\text {-Male } \\
\text {-Female }\end{array}$ & $\begin{array}{l}23(54.8) \\
19(45.2)\end{array}$ & $\begin{array}{l}13(39.4) \\
20(60.6)\end{array}$ & 0.19 \\
\hline $\begin{array}{l}\text { BMI }\left(\mathbf{k g} / \mathbf{m}^{2}\right): \\
\text { Mean } \pm \text { SD } \\
\text { Range }\end{array}$ & $\begin{array}{c}25.6 \pm 1.1 \\
23.9-27.89\end{array}$ & $\begin{array}{c}26 \pm 1.2 \\
23.44-28.3\end{array}$ & 0.16 \\
\hline Sever asthma $(\mathbf{n}, \%)$ & $12(28.6 \%)$ & $8(24.2 \%)$ & 0.33\# \\
\hline $\begin{array}{l}\text { FEV1/FVC: } \\
\text { Mean } \pm \text { SD }\end{array}$ & $62.8 \pm 6.8$ & $62.8 \pm 7.1$ & 0.98 \\
\hline $\begin{array}{l}\text { BDFEV1 (\%): } \\
\text { Mean } \pm \text { SD }\end{array}$ & $70.3 \pm 12.6$ & $70.6 \pm 13.5$ & 0.94 \\
\hline $\begin{array}{l}\text { Integrin } \beta 4 \mathrm{mRNA} \\
\text { expression (Iu/ml): } \\
\text { Mean } \pm \text { SD } \\
\text { Median(Range) }\end{array}$ & $\begin{array}{c}1.6 \pm 1.96 \\
0.7(0.06-5.8)\end{array}$ & $\begin{array}{c}4.6 \pm 1.92 \\
5.38(0.02-5.83)\end{array}$ & $<0.0001 *$ \\
\hline $\begin{array}{l}\text { IgE serum level } \\
(\text { Iu/ml): } \\
\text { Mean } \pm \text { SD } \\
\text { Median(Range) }\end{array}$ & $\begin{array}{c}442.7 \pm 36.3 \\
432(390-499)\end{array}$ & $\begin{array}{l}76.2 \pm 15.5 \\
79(47-96)\end{array}$ & $<0.0001 *$ \\
\hline
\end{tabular}

BMI: body mass index, FEV1: forced expiratory volume in one second, FVC: forced vital capacity, BDFEV1: bronchodilator forced expiratory volume in one second, $\mathrm{t}$ : $\mathrm{t}$ test, ${ }^{\#}$ Chi square test -*MannWhitney test 
Table (3): Statistical comparison of integrin $\beta 4 \mathrm{mRNA}$ expression and IgE serum levels among different degrees of severity in patients group

\begin{tabular}{|c|c|c|c|c|}
\hline & \multicolumn{3}{|c|}{ Patient group $(n=75)$} & \multirow[b]{2}{*}{$\begin{array}{c}P \\
\text { value }\end{array}$} \\
\hline & Mild (n=25) & $\begin{array}{c}\text { Moderate } \\
(\mathbf{n}=30)\end{array}$ & $\begin{array}{l}\text { Severe } \\
(n=20)\end{array}$ & \\
\hline $\begin{array}{l}\text { Integrin } \beta 4 \\
\text { mRNA } \\
\text { expression } \\
\text { (Iu/ml): } \\
\text { Mean+SD } \\
\text { Median (Range) }\end{array}$ & $\begin{array}{l}2.87 \pm 2.37 \\
2.3(0.02- \\
\quad 5.77)\end{array}$ & $\begin{array}{c}2.94 \pm 2.55 \\
2.28(0.06-5.8)\end{array}$ & $\begin{array}{l}2.77 \pm 2.48 \\
1.9(0.08- \\
\quad 5.8)\end{array}$ & $\mathbf{0 . 5 3}$ \\
\hline $\begin{array}{l}\text { IgE serum } \\
\text { level(Iu/ml): } \\
\text { Mean } \pm \text { SD } \\
\text { Median (Range) }\end{array}$ & $\begin{array}{c}244 \pm 199.2 \\
90(48-499)\end{array}$ & $\begin{array}{l}305.5 \pm 180.2 \\
405(60-498)\end{array}$ & $\begin{array}{c}291.1 \pm 178.6 \\
401.5(47- \\
499)\end{array}$ & 0.75 \\
\hline
\end{tabular}

Kruskal Wallis Test

Table (4): Correlation between integrin $\beta 4 \mathrm{mRNA}$ expression and studied parameters among patients

\begin{tabular}{|c|c|c|}
\hline \multirow{2}{*}{ Studied parameters } & \multicolumn{2}{|c|}{ Integrin $\beta 4$ mRNA expression (Iu/ml) } \\
\hline & $\mathbf{r}$ & P value \\
\hline Age (years): & 0.07 & 0.52 \\
\hline BMI $\left(\mathrm{kg} / \mathrm{m}^{2}\right):$ & 0.24 & 0.043 \\
\hline FEV1/FVC: & 0.12 & 0.32 \\
\hline BDFEV1 (\%): & -0.07 & 0.55 \\
\hline IgE serum level $(\mathrm{Iu} / \mathrm{ml})$ : & -0.39 & 0.001 \\
\hline
\end{tabular}

BMI: body mass index, FEV1: forced expiratory volume in one second, FVC: forced vital capacity, BDFEV1: bronchodilator forced expiratory volume in one second,r:

Spearman correlation coefficient 
Table (5): Correlation between IgE serum level and studied parameters among patients

\begin{tabular}{|l|c|c|}
\hline \multirow{2}{*}{ Studied parameters } & \multicolumn{2}{|c|}{ IgE serum level (Iu/ml) } \\
\cline { 2 - 3 } & r & P value \\
\hline Age $($ years): & -0.06 & 0.64 \\
\hline BMI $\left(\mathbf{k g} / \mathbf{m}^{2}\right):$ & -0.02 & 0.89 \\
\hline FEV1/FVC: & 0.02 & 0.87 \\
\hline BDEFV1 (\%): & 0.08 & 0.49 \\
\hline
\end{tabular}

BMI: body mass index, FEV1: forced expiratory volume in one second, FVC: forced vital capacity, BDFEV1: bronchodilator forced expiratory volume in one second, r: Spearman 's correlation coefficient

\section{DISSCUSION}

Bronchial Asthma is a complex disease of gene-environment interactions. The need is increasing for better understanding of the molecular mechanisms and identification of further susceptibility gene in asthma, some of which could be useful for diagnosis and improving treatments targeted to individual disease phenotypes (Blume and Davis2013).

In our study, we observed a significant decrease in the level of ITG $\beta 4$ mRNA expression in asthmatic patients mainly atopic casesirrespectiveof the degree of severity, confirming its relation to the asthma susceptibility (tables1-3).

Our data supported previous studies regarding ITG $\beta 4$ mRNA expression and bronchial asthma.The airway epithelial barrier is often disrupted in asthma patients, with evidence of shedding of airway epithelial cells and impaired expression of genes (Bucchieri et al., 2000).

Liu et al. 2010 Provided evidences that ITG $\beta 4$ was involved in the structural integrity and functional homeostasis of airway epithelial cells (Liu et al., 2010b).

The results of Zhou et al., 2008 and Xiang et al., 2014, showed that the expressions of integrin $\beta 4$ were down-regulated in asthma patients, and that it was associated with the variation in5'flanking region. 
It is likely that down-regulation of ITG $\beta 4$ in bronchial asthma contributes to the structural disruption and dysfunction of airway epithelial cells and may result in decreased wound repair and antioxidation ability (Evans and Koo 2009 \&Siddiquiad Martin 2008).

Moreover, Sheppard 2003 showed that integrin $\beta 4$ expression was clearly elevated after airway epithelialinjuryand could be detected in many cell types, which suggest that integrin $\beta 4$ might be involved in the repair processes of airway epithelium (Sheppard 2003).

Xiang et al., 2014 found thatmutations in 5 flanking region of integrin $\beta 4$ gene result in reduced integrin $\beta 4$ expression, and that it was related to increased risk of asthma (Xiang et al., 2014).

ITGs are heterodimeric receptors that mediate cell adhesion, migration and tissue organization(Staunton et al., 2006) and might be a death factor in endothelial cells (Hiran et al., 2003).

It is reported that disintegrin is increased in asthma.And it is related to asthma severity which may relates to downregulation of integrin(JiYeon et al., 2006) .

The study by Liu et al. 2012 demonstrated that downregulation of integrin $\beta 4$ expression in airway epithelial cells could impair the antigen presentation ability of these cellswith decreased Th1 cytokine production and increased Th2 cytokine production, which further regulates airway inflammation reaction in allergic asthma (Liu et al., 2012).

It is known that airway inflammation and airway hyperresponsiveness in asthma models were suppressed by Th1 cytokines(Park et al., 2009). On contrary, Th2 cytokines, such as IL-4 and IL-5, induce eosinophil infiltration and asthmatic airway hyperresponsiveness(Holgate, 2008).

Integrins are cellular receptors that regulate attraction of eosinophils from the bronchial circulation to the airway wall and airspace (Barthel et al., 2008).

This could explain the significant association of ITG $\beta 4$ downregulation and increased serum total IgE among asthmatic patients in our study. It has been shown that the presence and the degree of airway hyper-responsiveness were related to the total $\operatorname{IgE}$ as expressed by the occurrence of asthma exacerbation or an asthma severity score (Wever-Hess J, 2000). 
Scarpelli et al. 2016 indicated increased postmortem serum total IgE in atopic individuals, irrespective of the cause of death (Scarpelli et al., 2016).

Also, Sky et al. (2016) stated that a one-year follow up study on a well controlled adult patients with atopic asthma showed that treatment with inhaled corticosteroids and leukotrienes receptor antagonists resulted in a marked decrease in elevated total serum IgEAb concentration with improvement in asthma control and asthma related quality life (Sky et al., 2016) proving the role of serum total $\mathrm{IgE}$ in atopic asthma.

In contrast, our data revealed a non-significant correlation regarding ITG $\beta 4$ mRNA expression and serum IgE with asthma severity indices or patients demographics (Tables 4,5). This could be attributed to the presence of atopy regardless of the severity of asthma or patients characteristics.Also, the distribution of atopic cases among the severity range of asthma could explain the non- significant association of lung function with atopic status in our study.

\section{Conclusion:}

From this study, it could be concluded that, down-regulation of ITG $\beta 4$ expression was significantly associated with asthma susceptibility especially in atopic cases irrespective of the degree of asthma severity.

\section{REFERENCES}

Acosta KB, Lorenzini Campos MN, Etcheverry SB and Zapata PD (2016): $\alpha 6 \beta 4$ Integrin Genetic Variations (A380T and R1281W) and Breast Cancer Risk in an Argentinian Population.Int J MolSci; 18, 17: $1-8$

Barczyk M, Carracedo S and Gullberg D (2010):Integrins. Cell Tissue Res; 339: 269-280.

Barthel SR, Johansson MW, McNamee DM and MosherDF(2008):. Roles of integrin activation in eosinophil function and the eosinophilic inflammation of asthma.JLeukoc Biol. 83(1): 112.

Blume C, Davis DE (2013): In vitro and ex vivo models of human asthma. Eur J PharmaBiopharm; 84(2): 394-400.

Bucchieri F, Richter A and Buchanan D (2000).Increased sensitivity of asthmatic bronchial epithelial cells to oxidant-induced injury.Am J RespirCrit Care Med; 161: A153 
Charalambopoulos $K$ and Karachalios $G$ (2000): Adhesion molecules and lungdisease. Pneumon; 13: 50-56.

Chung KF, Wenzel SE, Brozek JL, et al. International ERS/ATS Guidelines on Definition, Evaluation and Treatment of Severe Asthma. EurRespir J 2014;43:343-73.

Evans and Koo (2009): Airway mucus: the good, the bad, thesticky.PharmacolTher 121: 332-348.

Global Initiative for Asthma.Global Strategy for Asthma Management and Prevention.Updated 2016.available on www.ginasthma.org.

Hiran TS, Mazurikweicz B, Krenberig $\mathbf{F}$ and Rice $\mathrm{S}$ (2003):Endothelial expression of ITGBE4 is negatively regulated during angiogenesis. J Cell Scin; 3771-3781.

Holgate ST (2007): Epithelium dysfunction in asthma. J Allergy ClinImmunol; 120: 1233-1244.

Holgate ST (2008): Pathogenesis of asthma. ClinExp Allergy 38: 872-897.

Holgate ST and Davies DE (2009): Rethinking the pathogenesis of asthma.Immunity 31: 362-367.

Ji-Yeon L, Sung-Woo P, Hee K, et al(2006): A Disintegrin and Metalloproteinase 33 Protein in Patients with Asthma.A J OF RCCM; 173(7):729-735.

Johansson MW and Mosher DF (2013): Integrin activation States and eosinophilrecruitment in asthma. Front Pharmacol; 4 (33): 1-9.

Liu C, Liu HJ, Xiang Y, Tan YR, Zhu XL and Qin XQ (2010a): Wound repair and antioxidative capacity is regulated by ITGB4 in air way epithelial cells.Mol Cell Biochem;341(1-2):259-269.

Liu C, Qin X, Liu $H$ and Xiang Y (2012): Downregulation of integrin $\beta 4$ decreases the ability of airway epithelial cells to present antigens.PLoS One;7(4):e32060.

Liu C, Xiang Y, Liu H, Li Y, Tan Y, Zhu X, Zeng D, Li M, Zhang $L$ and Qin $X$ (2010b): Integrin beta4 was downregulated on the airway epithelia of asthma patients. ActaBiochimBiophys Sin; 42(8):538-47.

National Heart Lung and Blood Institute. Washington DC: Department of Health and Human Services; 2007. National Asthma Education and Prevention Program. Expert Panel Report 3: Guidelines for the Diagnosis and Management of Asthma. 
Park H, Lee C, Jung I, Lee J, Jeong Y, et al. (2009):Quercetin regulates Th1/Th2 balance in a murine model of asthma. IntImmunopharmacol 9: 261-267.

Scarpelli M, Keller S, Tran L and Palmiere C (2016): Postmortem serum levels of $\mathrm{IgE}$ and mast cell tryptase in fatal asthma. Forensic SciInt 269; 113-118.

Sheppard D (2003): Functions of pulmonary epithelial integrins: from develop-ment to disease. Physiol Rev; 83: 673 - 686.

Siddiqui S, Martin JG (2008): Structural aspects of airway remodeling in asthma. Curr Allergy, Asthma Rep 8: 540-547.

Sky J, Malonvisch A, Borres M, Lena Unden A, Andreason A, Lekander A and Alving K (2016): Parallel reductions of IgE and exhaled nitric oxide after optimized anti-inflammatory asthma treatment. Immunity, Inflammation and Disease 4(2); 182-190.

Staunton D.E et al. (2006): Targeting ITGs structure and function in disease. AdvImmuno. 111-157

Xiang Y, Zhou XY, Tan YR, Tan ML, Liu HJ, Liu C, Qu XP, Qin XQ (2014):Analysis on the relevance of asthmasusceptibilitywith the alteration of integrin $\beta 4$ expression.PLoSOne.16;9(4):e95533.

Watt FM (2002): Role of integrins in regulating epidermal adhesion, growth anddifferentiation. EMBO J; 21: 3919-3926.

Wever-Hess J, Kouwenberg J, Dueverman E, Hermans J and Wever AM (2000): Risk factors risk factors for exacerbation and hospital admission in asthma. PediaPulmonal; 250-6

Zhou XY, Tan YR, Xiang Y, et al., (2008): The correlation of integrin beta 4 expression and asthma.Cell Biology International, 32(3): S 67. 


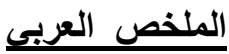

مستوى تعبير الحامض النووي الريبوزي الرسول انتجرين بيتاء فى المرضى المصابين بالربو الثعبى الترول التجر

عبير احمد محمد الرفاعى'، رباب عبد الرازق الوحش`،نسرين جمال الدين الهلباوى' قسمى' الكيمياءالحيويةالطبية ، 'الصدر - كلية الطب- جامعة|لمنوفية

يعتبر انتجرين بيتا ؛ واحد من مجمو عة الانتيجرين المسؤله على الحفاظ على سلامة الخلايـا

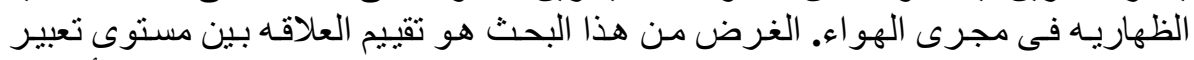

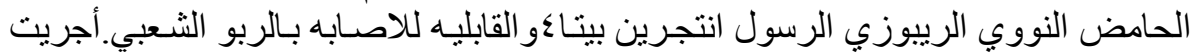

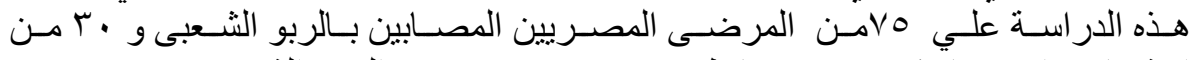





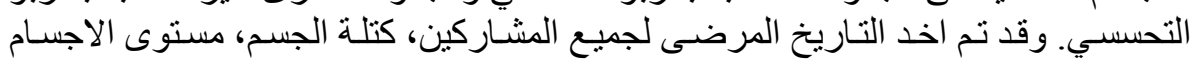

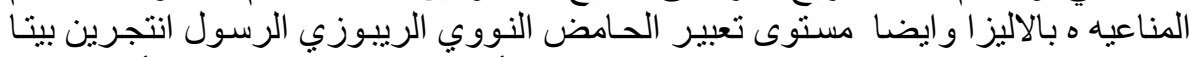

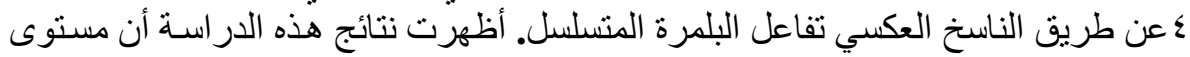

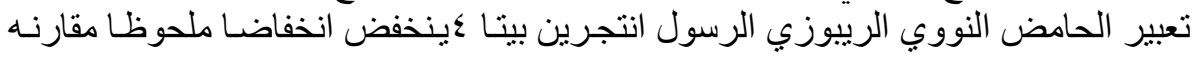

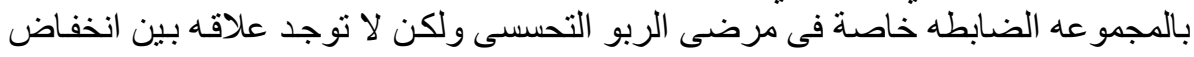

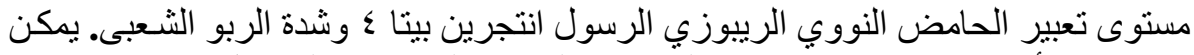

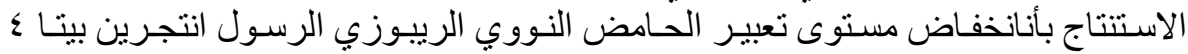

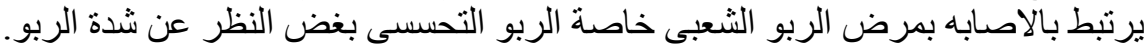

